\title{
MEMBANGUN DAN MENGEMBANGKAN SERTA MENINGKATKAN UMKM DI DESA TENGGAYUN
}

\author{
Irawan Fakhrudin Mahalizikri \\ Sekolah Tinggi Ilmu Ekonomi (STIE) Syariah Bengkalis \\ irawanfma@gmail.com
}

\begin{abstract}
Development of the physical sector which continues to advance along with the rapid advancement of science and technology needs to be balanced with the progress of society in nonphysical aspects. So far the progress of science and technology still leaves the community behind on non-physical aspects. Higher Education plays an important role in participating in the success of the National development program. The main objective of national development is the formation of modern Indonesian society but still adhering to the Pancasila and the 1945 Constitution. In Indonesia, the definition of micro small and medium enterprises is regulated in the Republic of Indonesia Law Number 20 of 2008 concerning micro small and medium enterprises. In the formation of this modern society, universities are tasked with creating experts who must have high knowledge and be able to develop their knowledge through technology that can ultimately be utilized by the Indonesian people as a whole. By following the pace of increasingly dynamic development steps to improve human resources both in the utilization and processing of natural resources and human resources. In implementing the knowledge possessed from various disciplines which henceforth can be applied in the midst of the community especially the Tenggayun village in terms of building and developing and enhancing micro, small and medium businesses.
\end{abstract}

Keywords: Micro Business, Small Business, Medium Business.

\begin{abstract}
ABSTRAK
Pembangunan disektor fisik yang terus malaju seiring dengan pesatnya kemajuan ilmu pengetahuan dan teknologi perlu diimbangi dengan kemajuan masyarakat pada aspek nonfisik. Sejauh ini kemajuan ilmu pengetahuan dan teknologi masih menyisakan ketertinggalan masyarakat pada aspek nonfisik. Perguruan Tinggi sangat berperan dalam ikut serta menyukseskan program pembangunan Nasional. Tujuan utama pembangunan Nasional adalah pembentukan masyarakat Indonesia yang modern namun tetap berpegang teguh pada Pancasila dan UUD 45. Di Indonesia, definisi UMKM diatur dalam undang-undang Republik Indonesia No. 20 Tahun 2008 tentang UMKM. Dalam pembentukan masyarakat yang modern ini, perguruan tinggi bertugas menciptakan tenaga-tenaga ahli yang harus memiliki pengetahuan tinggi dan mampu mengembangkan ilmunya melalui teknologi yang akhirnya bisa dimanfaatkan oleh masyarakat Indonesia secara keseluruhan. Dengan mengikuti derap langkah pembangunan yang semakin dinamis untuk meningkatkan sumber daya manusia baik dalam pemanfaatan serta pengolahan sumber daya alam dan sumber daya manusia. Dalam
\end{abstract}


mengimplementasikan keilmuan yang dimiliki dari berbagai disiplin ilmu yang untuk selanjutnya dapat diterapkan di tengah-tengah masyarakat khususnya desa tenggayun dalam hal membangun dan mengembangkan serta meningkatkan UMKM.

Kata kunci: Usaha Mikro, Usaha Kecil, Usaha Menengah.

\section{PENDAHULUAN}

Pembangunan disektor fisik yang terus malaju seiring dengan pesatnya kemajuan ilmu pengetahuan dan teknologi perlu diimbangi dengan kemajuan masyarakat pada aspek nonfisik. Sejauh ini kemajuan ilmu pengetahuan dan teknologi masih menyisakan ketertinggalan masyarakat pada aspek nonfisik. Dunia pendidikan, kesehatan masyarakat dan kesejahteraan masih jauh manjadi problem klasik yang butuh penanganan serius dari semua pihak. Perguruan Tinggi sangat berperan dalam ikut serta menyukseskan program pembangunan Nasional. Tujuan utama pembangunan Nasional adalah pembentukan masyarakat Indonesia yang modern namun tetap berpegang teguh pada Pancasila dan UUD 45. Dalam pembentukan masyarakat yang modern ini, perguruan tinggi bertugas menciptakan tenaga-tenaga ahli yang harus memiliki pengetahuan tinggi dan mampu mengembangkan ilmunya melalui teknologi yang akhirnya bisa dimanfaatkan oleh masyarakat Indonesia secara keseluruhan. Hal tersebut biasanya disebut dengan Tri Darma Perguruan Tinggi.

Di dalam hal ini Perguruan Tinggi kita kenal yang namanya Tri Darma Perguruan Tinggi, karena hal itu adalah tujuan dari didirikanya suatu perguruan tinggi, yaitu menciptakan lulusan mahasiswa yang berpendidikan, dan berguna tidak hanya untuk dirinya sendiri, namun juga berguna bagi masyarakat Indonesia,merupakan bentuk pengabdian nyata seorang dosen berserta mahasiswa yang pengabdian kepada masyarakat yang sebenarnya dalam hal membantu perekonomian dan pemberdayaan masyarakat desa.

Di Indonesia, definisi UMKM diatur dalam Undang-Undang Republik Indonesia No. 20 Tahun 2008 tentang UMKM. Pasal 1 dari undang-undang terebut, dinyatakan bahwa Usaha mikro adalah usaha produktif milik orang perorangan dan/atau badan usaha perorangan yang memiliki kriteria usaha mikro sebagaimana diatur dalam undang-undang tersebut yang dimaksud usaha kecil adalah usaha ekonomi produktif yang berdiri sendiri, yang dilakukan oleh orang perorangan atau badan usaha yang bukan merupakan anak perusahan atau bukan anak cabang yang dimiliki, dikuasai atau menjadi bagian, baik langsung maupun tidak langsung, dari usaha menengah atau usaha besar yang memenuhi kriteria usaha kecil sebagaimana dimaksud dalam undang-undang tersebut.

\section{TELAAH LITERATUR}

Keberhasilan setiap jenis usaha mempunyai keinginan untuk mencapai suatu titik yang disebut keberhasilan. Keberhasilan itu dapat diukur melalui pengukuran kinerja yang dapat dilihat dari berbagai aspek, seperti kinerja keuangan dan image perusahaan. Adhi (2009) mengemukakan bahwa keberhasilan usaha adalah bagaimana memulai, merawat, menjaga dan 
mengembang bisnis yang sudah terpenuhi, penyaluran yang produktif dan tercapainya tujuan organisasi, seperti gambar 1 pada teori motivasi supaya bisnis berjalan.

\section{Gambar 1 The Comfort Zone}

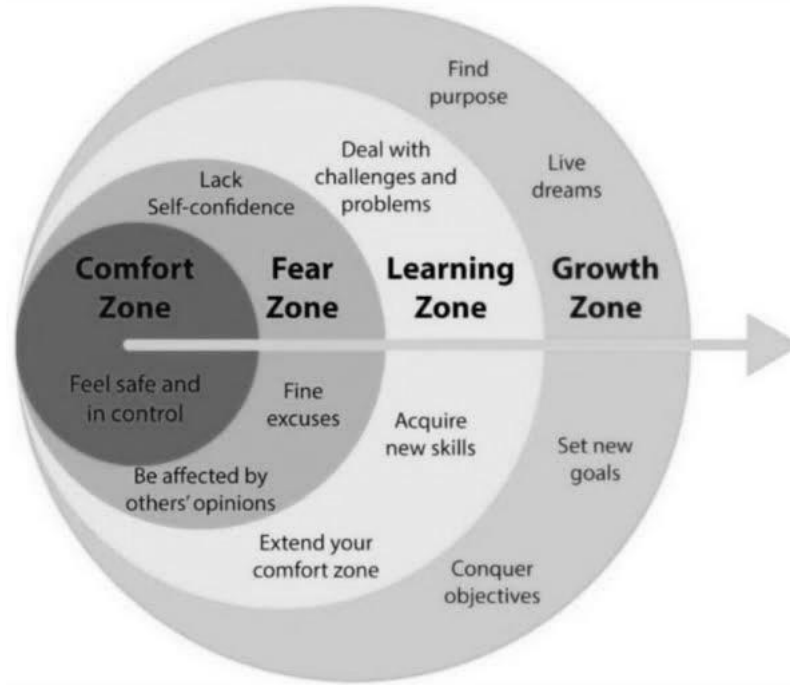

Algifari $(2003,118)$ berpendapat bahwa keberhasilan usaha dapat dilihat dari efisiensi proses produksi yang dikelompokkan berdasarkan efisiensi secara ekonomis. Sedangkan usaha mikro adalah usaha ekonomi produktif yang berdiri sendiri yang dilakukan oleh perorangan atau badan usaha yang bukan merupakan anak perusahaan atau bukan cabang perusahaan yang dimiliki, dikuasai, atau menjadi bagian baik langsung maupun tidak langsung dari usaha mikro, usaha kecil atau usaha besar yang memenuhi kriteria usaha mikro sebagaimana dimaksud dalam undang-undang tersebut.

Di dalam undang-undang tersebut, kriteria yang digunakan untuk mendefinisikan UMKM seperti yang tercantum dalam Pasal 6 adalah nilai kekayaan bersih atau nilai aset tidak termasuk tanah dan bangunan tempat usaha, atau hasil penjualan tahunan. Dengan kriteria sebagai berikut: (a) Usaha mikro adalah unit usaha yang memiliki aset paling banyak Rp. 50 juta tidak termasuk tanah dan bangunan tempat usaha dengan hasil penjualan tahunan paling besar Rp. 300 juta. (b) Usaha kecil dengan nilai aset lebih dari Rp. 50 juta sampai dengan paling banyak Rp. 500 juta tidak termasuk tanah dan bangunan tempat usaha memiliki hasil penjualan tahunan lebih dari Rp. 300 juta hingga maksimum Rp. 2.500.000. (c) Usaha menengah adalah perusahaan dengan nilai kekayaan bersih lebih dari Rp. 500 juta hingga paling banyak Rp. 100 milyar hasil penjualan tahunan di atas Rp. 2,5 milyar sampai paling tinggi Rp. 50 milyar.

Usaha mikro, kecil dan menengah merupakan pemain utama dalam kegiatan ekonomi di Indonesia. Masa depan pembangunan terletak pada kemampuan usaha mikro, kecil dan menengah untuk berkembang mandiri. Kontribusi usaha mikro, kecil dan menengah pada GDP di Indonesia tahun 1999 sekitar $60 \%$, dengan rincian $42 \%$ merupakan kontribusi usaha kecil dan mikro, serta $18 \%$ merupakan usaha menengah.

Pemberdayaan UMKM sangat penting dan strategis dalam mengantisipasi perekonomian kedepan terutama dalam memperkuat struktur perekonomian 
nasional. Adanya krisis perekonomian nasional seperti sekarang ini sangat mempengaruhi stabilitas nasional, ekonomi dan politik yang imbasnya berdampak pada kegiatan-kegiatan usaha besar yang semakin terpuruk, sementara UMKM serta koperasi relatif masih dapat mempertahankan kegiatan usahanya.

UMKM adalah unit usaha produktif yang berdiri sendiri, yang dilakukan oleh orang perorangan atau badan usaha di semua sektor ekonomi. Pada prinsipnya, pembedaan antara Usaha Mikro (UMI), Usaha Kecil (UK), Usaha Menengah (UM), dan Usaha Besar (UB) umumnya didasarkan pada nilai aset awal (tidak termasuk tanah dan bangunan), omset rata-rata per tahun, atau jumlah pekerja tetap. Namun definisi UMKM berdasarkan tiga alat ukur ini berbeda menurut negara. Karena itu, memang sulit membandingkan pentingnya atau peran UMKM antar negara.

Secara langsung akan menunjukkan keterkaitan langsung antara dunia pendidikan dalam upaya mewujudkan kesejahteraan masyarakat. Beberapa aspek yang diperhatikan dalam potensi desa yang ada yakni penelitan dan saling bertukar info sehingga dapat menghilangkan zona kenyaman dan beralih pada peluang pada masyarakat terhadap potensi desa yang berada pada zona nyaman sehingga ada inovasi dan menumbuhkan potensi desa terhadap UMKM yang telah ada. Pendekatan interdisipliner dan komprehensif yang bertolak dari permasalahan nyata masyarakat yang didekati dengan menggunakan segala ilmu pengetahuan, teknologi yang susah, sedang, dan atau akan dipelajari. Serta keberlanjutan dalam pengembangannya yang bertumpu pada sumber daya lokal dan potensi yang ada pada desa tersebut.

\section{PEMBAHASAN}

Desa Tenggayun merupakan desa yang perekonomiannya sudah berangsur membaik dan maju, terletak di kecamatan Bukit Batu kabupaten Bengkalis. Pada tahun 2017 terjadi pemekaran sehingga desa Tenggayun masuk ke kecamatan Bandar Laskamana.

Desa Tenggayun terbagi menjadi 3 dusun yaitu dusun Amelia, dusun Harapan dan dusun Meranti. Ada 6 RW dan 11 RT. Desa Tenggayun kecamatan Bandar Laksmana sebagian besar adalah daratan 13. 842, 15 ha. Desa tenggayun $70 \%$ diantaranya daerah pemukiman dengan kepadatan penduduk 2100 jiwa atau 589 Kepala Keluarga.

Desa Tenggayun sangat memperhatikan usia produktif terutama bidang pendidikan dikalangan masyarakat desa tersebut. Hal ini dengan dibuktikan dengan banyaknya sekolah yang ada di Desa Tenggayun. Dari hasil wawancara terdapat 1 TK, 2 SD, 1 MTS dan 1 MA. Dengan ini dapat dikatakan bahwa sektor pendidikan menjadi salah satu prioritas oleh Pemerintah Desa Tenggayun.

Desa Tenggayun kecamatan Bandar Laksmana memiliki satu tempat wisata yang sangat-sangat berpotensi sehingga dapat mengembangkan perekonomian masyarakat yakni pantai yaitu pantai hulu dan pantai hilir. Pantai dapat diartikan sebagai sebuah bentuk geografis yang terdiri dari pasir dan terdapat didaerah pesisir laut. Pantai ini sering dijadikan tempat wisata dan hiburan dikarenakan bentuknya yang indah serta pemandangan pasir dan air lautnya yang dapat menghibur diri serta menghilangkan kejenuhan dari kesibukan masyarakat disekitar desa Tenggayun. 
Dikarenakan pantai yang ada di desa Tenggayun merupakan salah satu pantai yang indah di kabupaten Bengkalis selain pantai Rupat dan pantai Selatbaru. Maka perlunya ada kerjasama dari masyarakat dan peran aparatur desa serta kebijakan yang mendukung untuk pengembangkan wisata pantai demi mewujudkan pertumbuhan ekonomi dari sektor pariwisata. Masyarakat diharapkan peduli akan kemajuan ekonomi di desanya atau yang ingin meningkatkan perekonomian di keluarganya maupun dirinya sendiri perlunya menyadari akan pentingnya peranan dari pariwisata untuk mendongkrak peningkatan pendapatan ekonomi.

\section{Monografi dan Sosiografi Desa}

Desa merupakan miniatur negara yang menjadi ujung tombak pembangunan. Oleh karena itu priotitas utama yang menjadi kajian terhadap desa Tenggayun yang merupakan salah satu wilayah administrasi Pemerintahan Daerah Kabupaten Bengkalis. Desa Tenggayun ini terletak di (Desa Tenggayun 2019):

Provinsi : Riau

Kabupaten : Bengkalis

Kecamatan : Bandar Laksamana

Dengan data sebagai berikut:

1. Luas wilayah

: $13.842,15$ ha

2. Batas desa

- Utara berbatasan dengan

- Selatan berbatasan dengan

: Selat Melaka

- Timur berbatasan dengan

: Pinggir

- Barat berbatasan dengan

: Desa Desa Api-api

3. Kelembagaan desa

: Desa Sepahat

Jumlah aparatur desa $\quad: 16$

Dusun

$: 3$

Rukun warga (RW) :6

Rukun tetangga (RT) : 11

Badan permusyawaratan desa (BPD) : :9

4. Kelembagaan masyarakat

Majlis taklim :7

Persatuan kematian $\quad: 1$

Lembaga swadaya masyarakat : :

Karang taruna : :

Remaja masjid $\quad: 1$

5. Kependudukan

Jumlah kepala keluarga $\quad: 589 \mathrm{kk}$

Jumlah penduduk : 2100 jiwa

a. Penduduk berdasarkan jenis kelamin

- Laki-laki

: 1013 orang

- Perempuan

: 1087 orang

b. Penduduk berdasarkan agama

- Islam

: 2098 orang

- Budha

: 2 orang

- Khatolik

$:-$

c. Penduduk berdasarkan suku 
- Melayu

: 600 orang

- Jawa

: 250 orang

- Batak

: 190 orang

- Cina

: 2 orang

d. Penduduk berdasarkan mata pencaharian

- Petani

: 120 orang

- Nelayan

: 40 orang

- Buruh Tani

: 52 orang

- Pegawai Negeri Sipil (PNS)

: 35 orang

- Pedagang Barang Kelontong

: 20 orang

- Karyawan Perusahaan Swasta

: 13 orang

- Wiraswasta

: 22 orang

- Buruh Harian Lepas

: 38 orang

- Tukang Jahit

: 7 orang

- Karyawan Honorer

: 38 orang

- Tukang Cukur

: 6 orang

- Tukang Las

: 2 orang

- Anggota Legislatif

: 1 orang

- Satpam/Security

- Apoteker

: 10 orang

- Guru masak

: 1 orang

: 4 orang

- Tukang rias

: 3 orang

- Tukang kue

: 15 orang

- Perangkat desa

: 14 orang

- Ibu Rumah Tangga

: 270 orang

- Pelajar

: 307 orang

- Belum Bekerja

: 108 orang

- Pembantu Rumah Tangga

: 7 orang

e. Penduduk berdasarkan pendidikan

- Belum sekolah

- TK

: 62 orang

- SD

$: 25$

- SLTP

: 276 orang

: 140 orang

- SLTA

: 51 orang

6. Sarana sosial pendidikan

a. Pendidikan anak usia dini (PAUD)

Jumlah sekolah

Jumlah murid

: 2 buah

Jumlah guru

: 30 orang

: 6 orang

b. Taman Kanak-Kanak

Jumlah sekolah

: 1 buah

Jumlah murid

: 25 orang

c. Taman pendidikan al-qur'an

Jumlah sekolah

: 1 buah

Jumlah murid

: 53 orang

Jumlah guru

: 5 orang

d. Sekolah dasar negri

Jumlah sekolah

: 2 buah 
Jumlah murid

Jumlah guru

e. Sekolah madrasah tsanawiyah

Jumlah sekolah

Jumlah murid

Jumlah guru

f. Sekolah madrasah aliyah

Jumlah sekolah

Jumlah murid

Jumlah guru

7. Sarana rumah ibadah

Masjid

Mushola/surau

8. Sarana kesehatan

Puskesmas pembantu

Posyandu

Bidan

Perawat

Dukun bayi
: 276 orang

: 26 orang

: 1 buah

: 140 orang

: 23 orang

: 1 buah

: 51 orang

: 20 orang

: 1 buah

: 6 buah

: 1 unit

: 2 unit

: 1 orang

: 2 orang

: 2 orang

\section{Membangun Dan Menyembangkan Serta Meningkatkan Potensi UMKM Di Desa Tenggayun}

Desa tenggayun sebagian besar wilayahnya adalah pantai yang dapat memberikan nuansa alam berbeda dari pantai lainnya. Setiap tahun pantai ini disaat liburan dan hari raya Idul Fitri selalu dipadati dengan pengunjung untuk menikmati keindahan alam baik itu pengunjung dari desa Tenggayun maupun dari luar Tenggayun.

Disekitar pantai ini ada pengeringan ikan milik masyarakat, sehingga menambah daya tarik tersendiri. Sambil bermain, anak-anak dapat mengenal rumah pengeringannya ikan yang jadi tempat usaha pada kehidupan masyarakat nelayan di Desa Tenggayun. Pengunjung tidak hanya melihat tetapi bisa membeli langsung dari nelayan.

Dengan adanya potensi tersebut masyarakat desa tenggayun dapat memanfaatkan sebagai sumber ekonomi masyarakat. Masyarakat bisa membuka warung makan dan ini juga dapat dimanfaatkan oleh ibu-ibu khususnya ibu PKK untuk menciptakan barang kreatif untuk dijadikan souvenir desa Tenggayun. Dan juga dapat membangun rumah penginapan khususnya untuk para pengunjung dari luar Tenggayun.

Ada beberapa potensi desa yang dapat dikembangkan yang memiliki peluang cukup besar untuk dijadikan sebuah upaya peningkatan perekonomian desa diantaranya:

Pertanian, masyarakat desa Tenggayun mayoritas mata pencariannya adalah sebagai petani dan nelayan. Salah satu potensi yang paling besar yang ada di desa Tenggayun adalah dalam sektor pertanian. Pertanian yang dimaksud meliputi tanaman karet dan sawit. Pada umumnya hasil dari karet dan sawit di jual ke tauke.

Nelayan, merupakan salah satu mata pencarian masyarakat desa Tenggayun. Hampir sebagian laki-laki yang tinggal di Desa Tenggayun tahu cara menjaring 
ikan. Masyarakat menganggap nelayan merupakan pekerjaan sampingan ada juga yang mengatakan bahwa nelayan merupakan sebuah hobi. Hasil tangkapan dari nelayan ada yang langsung dijual ke tauke atau untuk dikonsumsi sendiri, jarang ditemukan untuk dijual kewarung atau keluar desa Tenggayun. Apabila ada pengunjung datang untuk membeli ikan atau jenis tangkapan lainnya, barulah mereka menjualnya di rumah kediaman masing-masing. Namun apabila dilihat dari potensi yang lebih besar berada pada panorama pantainya atau lebih ditekankan pada wisata bahari namun pengelolaan yang belum maksimal serta dukungan aparatur desa yang masih kurang sehingga wisata tersebut tidak berkembang.

Namun apabila dilihat pada garis besarnya aparatur desa dan masyarakat belum terbiasa untuk menumbuh kembangkan yang namanya PELUANG.

$\mathrm{P}=$ perhatikan skeliling anda

$\mathrm{E}=$ evaluasi kekuatan diri

$\mathrm{L}=$ lihat perkembangan

$\mathrm{U}=$ ubah yang ada (modifikasi)

$\mathrm{A}=$ antisipasi perubahan

$\mathrm{N}=$ nomor satukan pelanggan

$\mathrm{G}=$ gerakan pasar ke arah anda

Masyarakat desa Tenggayun kebanyak terlena dengan kebiasaan hidup yang sudah ada sehingga berada pada zona nyaman, takut untuk berbuat sesuatu dan menumbuh kembangkan yang namanya PELUANG. Sehingga potensi yang sudah ada dan UMKM yang telah terlaksana tidak berkembang, seperti yang dikemukakan oleh Crouplay bahwa penunjukan hubungan antara tahap-tahapan proses kreatif memerlukan kombinasi antara interaksi dan psikologis serta menghubungkan dan menggabungkan unsur-unsur yang tidak lazim dengan yang lazim atau cara yang tak terduga. Proses pembangunan ini di mana masyarakat berinisiatif untuk memulai proses kegiatan sosial untuk memperbaiki situasi dan kondisi diri sendiri. Pemberdayaan masyarakat hanya bisa terjadi apabila masyarakat itu sendiri ikut pula berpartisipasi.

Tidak dapat dipungkiri bahwa banyak sekali manfaat yang bisa didapat dari wirausaha sosial. Salah satunya adalah dalam hal peningkatan taraf kesejahteraan masyarakat. Selain dapat menyejahterakan masyarakat, wirausaha sosial juga dapat menjadi solusi akan berbagai masalah sosial yang ada. Tentunya tidak melupakan faktor sumber daya manusia yang juga berkontribusi dalam kegiatan tersebut. Dalam memecahkan masalah sosial yang ada, dibutuhkan berbagai ide dan strategi agar hasil dan solusi yang didapat bisa maksimal. Untuk para pemula di bidang bisnis maupun para wirausahawan, beberapa cara di bawah ini kiranya dapat menjadi acuan untuk mengupayakan pemberdayaan masyarakat melalui wirausaha sosial:

Menjadi penyalur hasil produksi masyarakat. Mereka yang menjadikan wirausaha sosial sebagai cara dalam pemberdayaan masyarakat secara tidak langsung akan menjadi penyalur hasil produksi dari masyarakat. Contohnya adalah produksi kerajinan tangan. Masyarakat yang turut serta berkontribusi dalam kegiatan wirausaha sosial dapat mendistribusikan hasil produksi kerajinan tersebut dari mulut ke mulut maupun dengan bantuan media sosial. Hal ini juga dapat menjadi sarana apresiasi akan produksi yang telah dihasilkan. Jadi, tentu saja pemberdayaan masyarakat dalam hal ini sangat penting karena mereka dapat 
menjadi penyalur hasil produksi. Dengan begitu, proses distribusi pun dapat berjalan dengan baik.

Memberdayakan masyarakat sebagai Sumber Daya Manusia. Sumber Daya Manusia (SDM) yang baik adalah salah satu faktor penentu sukses atau tidaknya suatu wirausaha sosial. Pemberdayaan masyarakat dapat dilakukan dengan melakukan berbagai pelatihan untuk menambah kemampuan dan wawasan. Dengan begitu, bukan hanya wirausaha sosial saja akan terbantu, tapi juga bisa membantu masyarakat dari segi edukasi dan penambahan skill. Adanya trial dan error dalam setiap pelatihan itu hal biasa apalagi dengan latar belakang pengalaman seseorang yang masih minim. Namun, dengan kegigihan dan pelatihan yang konsisten, masyarakat daerah bisa menjadi sebuah aset SDM bagi masyarakat itu sendiri.

\section{KESIMPULAN}

Berdasarkan hasil survei dan analisa penulis serta penelitian yang dilakukan di desa Tenggayun kecamatan Bandar Laksamana kabupaten Bengkalis bahwa dengan pengembangan wisata pantai, maka masyarakat disekitar akan mendapat kemudahan terutama para pengusaha kecil dan menengah untuk lebih kreatif dan inovatif di dalam melakukan usaha dan memberdayakan semua pihak yang ada dan mempunyai andil besar. Salah satunya untuk menarik wisatawan, para pengusaha tersebut membuat suatu inovasi seperti menjual souvenir yang akan dijual kepada wisatawan yang unik merupakan hasil dari kerajinan tangan masyarakat setempat. Dari hasil UMKM tersebut masyarakat yang menjalani aktivitas sebagai nelayan dapat terbantu perekonomiannya. Kemudian para wisatawan datang berkunjung ke pantai Tenggayun, selain menikmati keindahan pantai mereka dapat membeli souvenir, ikan dan ikan asin di rumah warga yang berada disekitar pantai Tenggayun. Meningkatkan eksistensi pantai wisata desa Tenggayun dengan mempromosikan pantai secara efektif melalui media online seperti halaman web dan media sosial maupun secara offline melalui media-media konvensional. Pengembangan masyarakat di sektor pariwisata akan lebih efektif dan efisien jika pemerintah desa Tenggayun lebih mendukung kegiatan yang dilakukan oleh masyarakat yang nantinya juga akan berdampak pada pengembangan sektor pantai tenggayun agar lebih dikenal oleh masyarakat luas. Dalam mengolah potensi tersebut masih diperlukan perhatian yang lebih dari pemerintah daerah Kabupaten Bengkalis untuk menindak lanjuti temuan-temuan penulis sebagai masukan dan acuan dalam melaksanakan pemerataan ekonomi.

\section{DAFTAR PUSTAKA}

Adhi, Ariwibowo S. 2009. Kecerdasan Enterpreneur: Memulai, Membangun, Merawat, dan Mengembangkan Bisnis Anda. Jakarta: PT. Elex Media Kompetindo.

Algifari. 2003. Ekonomi Mikro Teori dan Kasus, Edisi ke-1 Cetakan Pertama. Yogyakarta: Bagian Penerbitan Sekolah Tinggi Ilmu Ekonomi YKPN.

Bahri, Saiful. 2018. "Inkubasi Bisnis Dan Usaha Kecil Di Bengkalis". IQTISHADUNA: Jurnal Ilmiah Ekonomi Kita 7 (2), 196 -203. 
Batubara, Zakaria. 2013. "Islam Dan Pemberdayaan Ekonomi Umat". IQTISHADUNA: Jurnal Ilmiah Ekonomi Kita 2 (2), 524-548.

Desa Tenggayun. 2019. Dokumentasi: Monografi Desa Tenggayun Tahun 2019.

Handani, M. 2010. Enterpreneurship: Kiat Melihat dan Memberdayakan Potensi Bisnis. Jakarta: PT. Buku Kita.

Mahalizikri, Irawan Fakhrudin. 2019. "Membangun Masyarakat Desa Melalui Pemberdayaan Ekonomi Dengan Budidaya Tanaman Pucuk Merah Pada Unit Usaha BUMDes Desa Sepotong”. IQTISHADUNA: Jurnal Ilmiah Ekonomi Kita 8 (1), 89-100.

Mansur, I. 2015. Bisnis dan Budidaya 18 Kayu Komersial. Cetakan pertama. Jakarta: Swadaya.

Mashuri. 2016. "Peran Baitul Maal Wa Tamwil (BMT) Dalam Upaya Pemberdayaan Ekonomi Masyarakat". IQTISHADUNA: Jurnal Ilmiah Ekonomi Kita 5 (2), 114-123.

Nofita Hapsari. 2014. Tri Darma Perguruan Tinggi. Diakses dari: http://nofitahapsari.blogspot.com/2014/06/makalah-tri-darma-perguruantinggi_2.html, tanggal 4 September 2019 jam 9:32. 